\title{
Indigofera suffruticosa Mill (Fabaceae): Hepatic Responses in Mice Bearing Sarcoma 180
}

\author{
Indigofera suffruticosa Mill (Fabaceae): Respuestas Hepáticas \\ en Ratones Portadores de Sarcoma 180
}

\author{
Ivanise Brito da Silva*; Izabela Rangel Lima*; Marllon Alex Nascimento Santana*; \\ Roberta Maria Pereira Leite* \& Sônia Pereira Leite*
}

DA SILVA, I. B.; LIMA, I. R.; SANTANA, M. A. N.; LEITE, R. M. P. \& LEITE, S. P. Indigofera suffruticosa Mill (Fabaceae): hepatic responses in mice bearing sarcoma 180. Int. J. Morphol., 32(4):1228-1233, 2014.

SUMMARY: Indigofera suffruticosa is a plant generally used to treat infectious and inflammatory processes. This work aims to evaluate the histopathological changes in the liver tissue of mice with Sarcoma 180 after subchronic treatment with aqueous extract obtained by infusion and maceration of Indigofera suffruticosa leaves. Male mice were divided into four groups of six animals: G1, G2 and G3 patients with Sarcoma 180 and Sarcoma 180 G4 without sarcoma. G1 and G2 were treated with infusion mashing respectively (50 mg/kg ip); G3 and G4 controls received saline (15 ml/kg ip). The histopathological and morphometric analysis of liver tissue after subchronic treatment with aqueous extracts by infusion and maceration of the groups G1, G2 and G4 were similar and showed no degraded areas or leukocyte infiltration compared to G3, which shows a marked destruction of liver architecture. The results showed that after subchronic treatment with the aqueous extract of leaves Indigofera Suffruticosa obtained by infusion and maceration, the hepatic architecture was preserved, suggesting its use as an alternative hepatoprotective agent.

KEY WORDS: Liver; I. suffruticosa; Histopathology; Histomorphometry; Sarcoma 180.

\section{INTRODUCTION}

The importance of research on medicinal plants in developing countries such as Brazil takes on several grounds among which we highlight the fact that despite being the country with the highest plant biodiversity in the world, the growth of research in this area is less than $10 \%$ a year (Mariz, 2007). This fact complicates the rational use of herbal medicines by the general population, for the treatment of various diseases (Mariz). Many hepatoprotective herbal preparations have been recommended in alternative systems of medicine for the treatment of hepatic disorders (Balderas-Renteria et al., 2007). Much of the therapeutic arsenal used in cancer treatment has significant impact on the gastrointestinal tract. Histological observations are important tools to detect tissue and cell alterations caused by xenobiotic compounds.

Species belonging to the Fabaceae, Indigofera suffruticosa Mill have been used by the Brazilian population for the treatment of infectious and inflammatory processes. Some pharmacological studies using aqueous extract of $I$. suffruticosa have shown embryotoxic (Leite et al., 2004) antimicrobial (Leite et al., 2006), anti-inflammatory (Leite et al., 2003), antitumor and cytotoxic activities (Vieira et al., 2007).

A chemical investigation of leaves extract of $I$. suffruticosa in Natural Products Alert (NAPRALERT, 2003) and Chemical Abstracts databases has revealed the presence of alkaloids, flavanoids, steroids, proteins, carbohydrates and indigo (Leite et al., 2003). The indigoids, indigo and indirubina, derived from the Indican compound have shown an antitumor activity on Sarcoma 180 and Ehrlich Carcinoma in Swiss albino mice (Maranhão, 2008). In phytochemical studies of I. suffruticosa leaves the Indican was identified, isolated and purified (Vieira, 2011). Recently, protective effects on liver tissue, antitumor activity and embryotoxicity on Aedes aegypti have been tested with extract of I. suffruticosa leaves (Lima, 2012; Vieira et al., 2012). In the present study, we have investigated the liver tissue of mice bearing Sarcoma 180 submitted to subchronic treatment with aqueous extract of Indigofera suffruticosa leaves obtained by infusion and maceration.

\footnotetext{
* Department of Histology and Embryology, Center of Biological Sciences, Federal University of Pernambuco, Recife, Brazil.
} 


\section{MATERIAL AND METHOD}

Plant Material. The leaves of Indigofera suffruticosa Mill were collected in June 2009 in Nova Cruz, State of Pernambuco, Brazil, and authenticated by the Biologist Marlene Barbosa from the Botanic Department, Federal University of Pernambuco (UFPE), Brazil. A voucher specimen number 32859 has been deposited at the Herbarium of the aforementioned department. Two extracts were prepared by infusion and maceration from $150 \mathrm{~g}$ of leaves of I. suffruticosa. The leaves were weighed, chopped and extracted with solvents and water. The infusion was prepared with $75 \mathrm{~g}$ of fresh leaves in $2 \times 200 \mathrm{ml}$ of increasing polarity solvents (hexane, ethyl acetate and methanol) at $40^{\circ} \mathrm{C}$ for $10 \mathrm{~min}$ and solid matter was removed by filtration. After this preliminary step, the same plant material was extracted in boiling distilled water under the same conditions, and the maceration obtained following the above mentioned process at room temperature $\left(28^{\circ} \mathrm{C}\right)$ overnight. The solvents were removed by rotary evaporation. The yields $(w / w)$ of the infusion and the maceration were hexane (0.67 and $0.74 \%)$, ethyl acetate $(0.39$ and $0.34 \%$ ), methanol (3.9 and $1.88 \%$ ) in terms of newly collected plant material. After lyophilization, the aqueous extracts yielded 4.20 and $1.75 \%$ and the dried material was stored at $20^{\circ} \mathrm{C}$. The aqueous extracts by infusion and maceration were used for subchronic treatment in mice bearing Sarcoma 180.

Mouse Experiments. Male Swiss albino mice, 50 days, weighing 25-35 g were purchased from the animal house of Centro de Pesquisas Aggeu Magalhães (Recife, Pernambuco, Brazil). They were housed in standard environmental conditions of temperature, humidity and under clear and dark cycles of $12 \mathrm{~h}$. The mice were fed with the diet of the vivarium (LABINA Purina Recife-PE, Brazil) and water ad libitum. The animals used in the experiment were kept and handled in accordance to Ethical Principles for Animal Research required by the Brazilian College for Animal Experimentation (COBEA).

Treatment protocol. Sarcoma 180, solid tumor, was obtained from the Department of Antibiotics, UFPE, Brazil. The solid tumor was maintained in Swiss albino mice male. Four groups (G1, G2, G3 and G4) of 6 animals were used. Sarcoma cell line $180(0.3 \mathrm{~mL})$ were injected in the peritoneum of mice in groups G1, G2 and G3 (approximately $3 \times 10^{6}$ cells). After 48 hours, $15 \mathrm{~mL} / \mathrm{kg}$, i.p. of saline solution were administered in control groups G3 and G4. The chemotherapy was initiated making use of aqueous extract from leaves of I. suffruticosa in G1/Infusion and G2/ maceration with daily administration of $50 \mathrm{mg} / \mathrm{kg}$ i.p. during seven consecutive days. The dose of the compound was based on the LD50 (Leite et al., 2004). On the eighth day, the mice were sacrificed by cervical dislocation and the livers were removed for histopathological and histomorphometric studies.

Histopathological and histomorphometric studies of liver. Liver from treated (G1 and G2) and controls groups (G3 and G4) were fixed in formaldehyde (2.5\%) and stained with hematoxylin and eosin (HE) (Masson, 1956; Sprando, 2007). A total of 30 histological preparations were studied by analysis of four random fields. The histological preparations were digitized with $20 ¥$ final magnification using a video digital camera (Leica DFC 280, Wetzlar, Germany) coupled to a light microscope (Leica Mikroskopie \& Systems GmbH, Wetzlar, Germany).

Morphometric evaluation of the area and of the perimeter of hepatocytes nucleus and diameter of the sinusoidal capillaries were performed using the Scion Image software (Scion Corporation, New York, USA).

Statistical analysis. The results for the area and perimeter of nucleus hepatocytes and diameter of the sinusoidal capillaries were expressed as mean \pm SEM (standard error mean) and analyzed by the Holm-Sidak method: Overall significance level $\leq 0.05$.

\section{RESULTS}

Histopathology and histomorphometry of liver. The histopathological analysis of the liver of mice bearing Sarcoma 180 after subchronic treatment with aqueous extracts by infusion (G1), maceration (G2) at a dose of $50 \mathrm{mg} / \mathrm{kg}$ i.p. and of the control group without Sarcoma 180/saline (G4) treated with saline solution ( $15 \mathrm{ml} / \mathrm{kg}$ i.p. $)$, showed a normal liver architecture; cords of hepatocytes $(\mathrm{CH})$ very well arranged, sinusoidal capillaries (S) and central veins (CV) without alterations (Fig. 1, panel G1, G2 and G4) compared with that of the mice bearing Sarcoma 180/saline (G3) sinusoidal congestion, hepatocyte necrosis and degeneration of liver cells.

The histomorphometric analysis of area and perimeter of nucleus of hepatocytes from treated and control groups were randomly compared in Figure 2; G1 by infusion $(51.00 \pm 14.59$ and $26.24 \pm 3.89 \mu \mathrm{m})$ when compared with $\mathrm{G} 2$ by maceration $(47.09 \pm 12.97$ and $27.00 \pm 4.61 \mu \mathrm{m})$ did not show significant statistical difference. G1 by infusion $(51.00 \pm 14.59$ and $26.24 \pm 3.89 \mu \mathrm{m})$ and $\mathrm{G} 2$ by maceration $(47.09 \pm 12.97$ and $27.00 \pm 4.61 \mu \mathrm{m})$ when compared with control groups G3 with sarcoma $(38.19 \pm 10.15$ and 




Fig. 1. Photomicrographs of hepatic tissue of Swiss albino mice: (G1) bearing sarcoma 180/administered infusion; (G2) bearing sarcoma 180/administered Maceration (G3) bearing sarcoma 180/administered saline; (G4) without Sarcoma 180 administered saline. Formalin fixed, HE- stained. Hepatocyte nucleus (HN); Sinusoids capillarie (S); Central veins (CV). 400X Magnification.

$23.29 \pm 2.52)$ and $\mathrm{G} 4$ without sarcoma $(24.23 \pm 7.18$ and $18.73 \pm 2.52 \mu \mathrm{m})$ showed statistically significant difference. The control groups G3 with sarcoma (38.19 \pm 10.15 and $23.29 \pm 2.52 \mu \mathrm{m}$ ) when compared with G4 without sarcoma $(24.23 \pm 7.18$ and $18.73 \pm 2.52 \mu \mathrm{m})$ showed statistically significant difference.

The diameter of hepatic sinusoidal capillaries (Figure 3) did not show significant statistical difference when the groups $\mathrm{G} 1$ by infusion $(4,64 \pm 1,13 \mu \mathrm{m})$ and G2 by maceration $(4,69 \pm 1,25 \mu \mathrm{m})$ were compared, as well as the control groups G3 with sarcoma $(3,20 \pm 1,03 \mu \mathrm{m})$ and $\mathrm{G} 4$

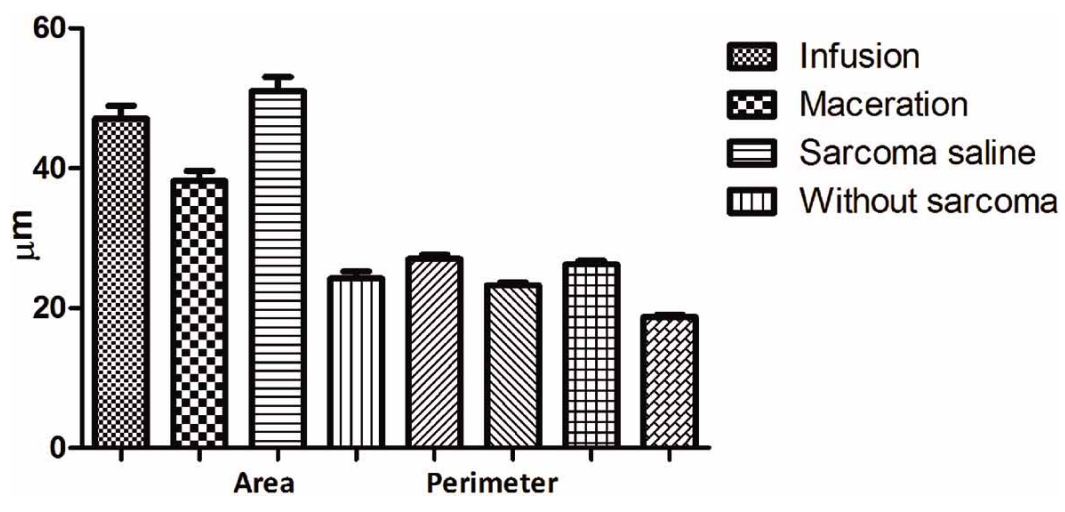

Fig. 2. Histomorphometry of the area and perimeter of the hepatocyte nuclei of the mice: G1: mice bearing sarcoma 180/administered infusion; (G2) bearing sarcoma 180/administered Maceration (G3) bearing sarcoma 180/administered saline; (G4) without Sarcoma 180 administered saline. The results are expressed as mean \pm SD and the data were evaluated by Holm-Sidak method ( $\mathrm{f} 0.05$ ). $\mathrm{n}=200$ hepatocyte nuclei. 
without sarcoma $(3,46 \pm 1,22 \mu \mathrm{m})$. However, the groups $\mathrm{G} 1$ by infusion $(4,64 \pm 1,13 \mu \mathrm{m})$ and $\mathrm{G} 2$ by maceration $(4,69 \pm 1,25 \mu \mathrm{m})$, when compared with the control groups G3 with sarcoma $(3,20 \pm 1,03 \mu \mathrm{m})$ and G4 .

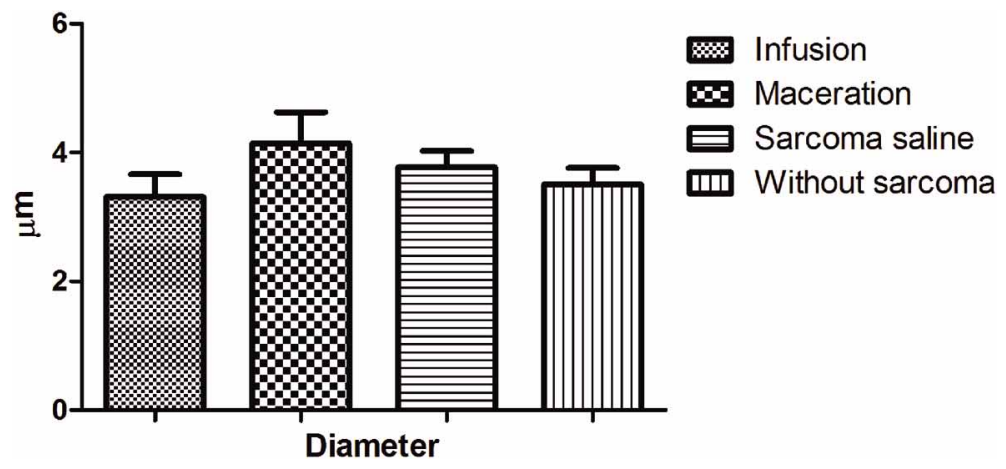

Fig. 3. Histomorphometry of the diameters of the hepatic sinusoid capillaries of the mice: Sonusoids - G1: mice bearing sarcoma 180/administered infusion; (G2) bearing sarcoma 180/administered Maceration (G3) bearing sarcoma 180/ administered saline; (G4) without Sarcoma 180/administered saline. Data are expressed as mean $\pm \mathrm{SD}$ and the data were evaluated by Holm-Sidak method (p£0.05). $n=200$ sinusoid capillaries.

\section{DISCUSSION}

Many hepatoprotective herbal preparations have been recommended in alternative systems of medicine for the treatment of hepatic disorders (Balderas-Renteria et al.). The liver is an organ of paramount importance and plays a significant role in the metabolism and detoxification of exogenous toxins and therapeutic agents (Ram, 2001; Ramachandra Setty et al., 2007). Much of the therapeutic arsenal used in cancer treatment has significant impact on the gastrointestinal tract. Histological observation is an important tool for the detection of morphologic changes in the liver caused by bioactive compounds. The plants belonging to the Fabacea family have medicinal properties, especially the I. suffruticosa plant. According to the results found by Vieira et al. (2007a) aqueous extracts of I. suffruticosa leaves by infusion (64.53\%) and maceration $(62.62 \%)$ were used on Sarcoma 180 in mice at a dose of $50 \mathrm{mg} / \mathrm{kg}$ i.p. and showed a tumor reducing activity. From the data of that study, histological analysis was performed and it showed that there was no structural alteration in the liver tissue of mice bearing sarcoma 180 after subchronic treatment with aqueous extracts of leaves of I. suffruticosa by infusion and maceration. Our data corroborate the results found by Silva et al. (2012) which demonstrated that the aqueous extracts of I. suffruticosa leaves preserved the liver architectures, Lima suggested as well its use as an alternative protective agent of the liver tissue. In this study, leukocyte infiltration was not found in the liver of mice treated with aqueous extracts by infusion and maceration, corroborating with the antiinflammatory activity of the leaf extract of I. suffruticosa described by Leite et al. (2003). The aqueous extract of I. suffruticosa leaves obtained by infusion showed low order of toxicity in mice at least up to the maximum concentration of $2400 \mathrm{mg} / \mathrm{kg}$ and no death but some low signs of toxicity (Vieira et al., 2007a).

The results of the histomorphometric analysis of the area and perimeter of the hepatocyte nucleus of mice bearing Sarcoma 180 after subchronic treatment with aqueous extracts by infusion was similar when compared with maceration. Infusion and maceration extracts did not show significant statistical differences, however, protective effect on liver tissue of mice bearing Sarcoma 180 submitted to treatment with extracts is dose-dependent and these results corroborate with tumor reducing activity found by Vieira et al. (2007a). The hepatocyte nucleus after subchronic treatment with infusion and maceration showed a significant increase when compared with control groups with and without sarcoma 180 . The results of the present study suggest that morphological alterations of the hepatocyte nuclei after subchronic treatment with aqueous extracts of I. suffruticosa leaves may be due to their interference with DNA synthesis. The same mechanisms of aqueous extract of $I$. suffruticosa leaves by infusion may be involved in the embryo development in mice (Leite et al., 2004). Biological activities of the compounds detected in the aqueous extracts of leaves of I. suffruticosa by infusion and maceration could be linked to antitumor activity found by Vieira et al. (2007b) and Silva et al. (2010). This will be the object of future researches as modulating lipid peroxidation and augmenting antioxidant defense system (superoxide dismutase and catalase), DNA synthesis, interaction with cell cycle regulation.

The results of histomorphometric analysis of the diameter of the hepatic sinusoid capillaries of mice bearing sarcoma 180 after subchronic treatment with infusion and maceration showed a significant increase compared with control groups with and without sarcoma 180, but no significant statistical difference between treated groups was found.

Our results concerning the aqueous extracts by infusion and maceration of $I$. 
suffruticosa leaves corroborate the results found by Lima which demonstrated that the Indican from leaves of $I$. suffruticosa preserved the architecture of sinusoidal capillaries suggesting its use as an alternative protective agent of the liver tissue. The efficacy of any hepatoprotective drug is essentially dependent on its ability to reduce the harmful effects or maintaining the normal hepatic physiology that has been disturbed by a hepatotoxin (Balderas-Renteria et al.; Raju et al., 2003). Silymarin extracted from the seeds of milk thistle (Silybum marianum) is composed of many polyphenolic flavonoids, including silibinin (the major one), isosilybin, silychristin and silidianin. Silymarin has been used for centuries due to its well-known hepatoprotective effect and it has various pharmacological properties (Jia et al., 2001).

\section{CONCLUSIONS}

The results of this investigation may improve our understanding about the usage of aqueous extracts by infusion and maceration from I. suffruticosa leaves as an alternative protective liver tissue agent. The biological activities of indigoids derived from Indican (Indigo and indirubina) from I. suffruticosa leaves remain to be studied. This is a promising plant for further studies regarding drug development.

ACKNOWLEDGMENTS. The authors thank the excellent technical support of Lúcia Maria Pires Ferreira, Department of Nutrition, Federal University of Pernambuco.

DA SILVA, I. B.; LIMA, I. R.; SANTANA, M. A. N.; LEITE, R. M. P. \& LEITE, S. P. Indigofera suffruticosa Mill (Fabaceae): respuestas hepáticas en ratones portadores de Sarcoma 180. Int. J. Morphol., 32(4):1228-1233, 2014.

RESUMEN: Indigofera suffruticosa es una planta utilizada para tratar procesos infecciosos e inflamatorios. Este trabajo tiene como objetivo evaluar los cambios histopatológicos en el tejido del hígado de ratones con sarcoma 180 después del tratamiento subcrónica con el extracto acuoso obtenido por infusión y maceración de las hojas de Indigofera suffruticosa. Los ratones machos fueron divididos en cuatro grupos de seis animales: pacientes G1 , G2 y G3 con Sarcoma 180 y G4 sin Sarcoma. G1 y G2 fueron tratados con infusión de maceración respectivamente (50mg/kg.ip); Controles G3 y G4 recibieron solución salina (15 ml/kg.ip). El análisis histopatológico y morfométrico de tejido hepático después de un tratamiento subcrónico con extractos acuosos por infusión y la maceración de los grupos G1, G2 y G4 fueron similares y no mostraron áreas degradadas o la infiltración de leucocitos en comparación a G3, que muestra una marcada destrucción de la arquitectura del hígado. Los resultados mostraron que después de un tratamiento subcrónico con el extracto acuoso de hojas de Indigofera suffruticosa obtenidos por infusión y la maceración, se conservó la arquitectura hepática, lo que sugiere su uso como una alternativa de agente hepatoprotector.

PALABRAS CLAVE: Hígado; I. suffruticosa; Histopatología; Histomorfometría; Sarcoma de 180.

\section{REFERENCES}

Balderas-Renteria, I.; Camacho-Corona, Mdel R.; Carranza-Rosales, P.; Lozano-Garza, H. G.; Castillo-Nava, D.; AlvarezMendoza, F. J. \& Tamez-Cantú, E. M. Hepatoprotective effect of Leucophyllum frutescens on Wistar albino rats intoxicated with carbon tetrachloride. Ann. Hepatol., 6(4):251-4, 2007.

Jia, J. D.; Bauer, M.; Cho, J. J.; Ruehl, M.; Milani, S.; Boigk, G.; Riecken, E. O. \& Schuppan, D. Antifibrotic effect of silymarin in rat secondary biliary fibrosis is mediated by downregulation of procollagen alpha1(I) and TIMP-1. J. Hepatol., 35(3):3928, 2001.

Raju, K.; Anbuganapathi, G.; Gokulakrishnan, V.; Rajkapoor, B.; Jayakar, B. \& Manian, S. Effect of dried fruits of Solanum nigrum LINN against CCl4-induced hepatic damage in rats. Biol. Pharm. Bull., 26(11):1618-9, 2003.

Leite, S. P.; de Medeiros, P. L.; da Silva, E. C.; de Souza Maia, M. B.; de Menezes Lima, V. L. \& Saul, D. E. Embryotoxicity in vitro with extract of Indigofera suffruticosa leaves. Reprod. Toxicol., 18(5):701-5, 2004.

Leite, S. P.; Silva, L. L. S.; Catanho, M. T. J. A.; Lima, E. O. \& Lima, V. L. M. Anti-inflammatory activity of Indigofera suffruticosa extract. Rebrasa, 7:47-52, 2003.

Leite, S. P.; Vieira, J. R.; de Medeiros, P. L.; Leite, R. M.; de Menezes Lima, V. L.; Xavier, H. S. \& de Oliveira Lima, E. Antimicrobial Activity of Indigofera suffruticosa. Evid. Based Complement. Alternat. Med., 3(2):261-5, 2006.

Lima, I. R. Investigação da Indigofera suffruticosa sobre atividade antitumoral e aspectos histológicos e morfométricos do tecido hepático de camundongos portadores de sarcoma 180. Tesis de Magister. Recife, Programa de Pós-graduação em Inovação Terapêutica. Universidade Federal de Pernambuco, 2012.

Maranhão, J. B. Indican, índigo e indirubina de folhas de Indigofera 
DA SILVA, I. B.; LIMA, I. R.; SANTANA, M. A. N.; LEITE, R. M. P. \& LEITE, S. P. Indigofera suffruticosa Mill (Fabaceae): hepatic responses in mice bearing sarcoma 180. Int. J. Morphol., 32(4):1228-1233, 2014

suffruticosa sobre linhagens celulares neoplásicas. Tesis de Magister. Recife, Programa de Pós-graduação em Patologia da Universidade Federal de Pernambuco. Departamento de Histologia e Embriologia, Universidade Federal de Pernambuco, 2008. pp.55.

Mariz, S. R. Estudo Toxicológico pré-clínico de Jatropa gossypiifolia L. Tese de Doctorado. João Pessoa, Programa de Pós-Graduação em Produtos Naturais e Sintéticos Bioativos, Universidade Federal da Paraíba, 2007. pp.186.

Masson, P. Tumeurs Humaines: Histologic. Diagnostics et Techiniques. $2^{\mathrm{a}}$ ed. Paris, Libraire Maloine, 1956. pp.106-48.

NAPRALERT - Natural Products Alert. Chicago, Illinois University, 2003. Disponible en: http://www.napralert.org/

Ram, V. J. Herbal preparations as a source of hepatoprotective agents. Drug News Perspect., 14(6):353-63, 2001.

Ramachandra Setty, S.; Quereshi, A. A; Viswanath Swamy, A. H.; Patil, T.; Prakash, T.; Prabhu, K. \& Veeran Gouda, A. Hepatoprotective activity of Calotropis procera flowers against paracetamol-induced hepatic injury in rats. Fitoterapia, 78(78):451-4, 2007.

Silva, I.B; Leite, S.P.: Avaliação dos efeitos do extrato aquoso e do indican isolado de Indigofera suffruticosa sobre a morfologia do tecido hepático de camundongos portadores de sarcoma 180. XX Congresso de Iniciação Científica da UFPE, 2012.

Sprando, R. L. Perfusion of the rat testis through the heart using heparin. In: Russell, L. D.; Ettlin, R. A.; Hikim, A. P. S.: Clegg, E. D. (Eds.). Histological and Histopathological Evaluation of the Testis. Clearwater, Cache River Press, 1990. pp.277-80.

Vieira, J. R. C. Investigação farmacognóstica e Biológica de Folhas Indigofera suffruticosa Mill sobre Aedes aegypti. Tese de Doutorado. Recife, Programa de Pós-graduação em Ciências Farmacêuticas da Universidade Federal de Pernambuco, 2011. pp.68.

Vieira, J. R.; de Souza, I. A.; do Nascimento, S. C. \& Leite, S. P. Indigofera suffruticosa: an alternative anticancer therapy. Evid. Based Complement. Alternat. Med., 4(3):355-9, 2007 a.

Vieira, J. R. C.; Souza, I. A.; Nascimento, S. C.; Leite, S. P. Atividade antitumoral de Indigofera suffruticosa. An. Fac. Med. (Universidade Federal de Pernambuco), 52(2):112-5, $2007 \mathrm{~b}$.

Vieira, J. R. C.; Leite, R. M. P.; Lima, I. R.; Navarro, D. A. F.; Bianco, E. M. \& Leite, S. P. Oviposition and Embryotoxicity of Indigofera suffruticosa on Early Development of Aedes aegypti (Diptera: Culicidae). Evid. Based Complement. Alternat. Med., 2012:741638, 2012.

\author{
Correspondence to: \\ Ivanise Brito da Silva \\ Department of Histology and Embryology \\ Center of Biological Sciences \\ Federal University of Pernambuco \\ Recife, PE \\ Brazil. \\ Email: ivanisebrito1@gmail.com
}

Received: 11-06-2014

Accepted: 14-08-2014 